\title{
Making copyright markets work for creators, consumers and the public interest
}

\author{
Jeremy de Beer
}

\section{Introduction and overview}

Copyright is an important part of marketplace framework policies that support creative industries. Copyright is also increasingly relevant to broader economic and industrial policy. Market-oriented justifications for copyright, therefore, factor heavily in debates about copyright law and policy reform. In this context, discourse often revolves around copyright as a property right, which underpins market transactions.

This chapter endorses market-oriented approaches towards copyright as a means to promote creators' interests, consumers' interests, and the public interest. The conception of copyright as a property right is consistent with the basis of general policymaking in free market economies. Two caveats are, however, important to understand how proprietary rights for creators can and do promote the public interest. First, like all property rights, copyrights are not absolute but appropriately limited by other individual rights and social values. Second, in order to function effectively, copyright entitlements should be structured to facilitate, not frustrate, free market transactions. 
This chapter explains why and how copyright's currently layered and fragmented bundles of rights inhibit the public interest in developing efficient copyright markets.

An appropriately limited and structurally simplified bundle of rights, as suggested in this chapter, would increase the efficiency of copyright markets and grow the size of creative industries. More efficient markets will lead to more choices and lower prices for consumers, as well as increased economic opportunities for creators to reach a larger market.

However, such market-oriented approaches may also concentrate power, increase inequality, and marginalise individual creators. This chapter mentions three practical mechanisms to address such concerns: collective bargaining to achieve fairer contracting in creative industries; class action litigation to enforce common rights of individual creators; and certified branding schemes to promote fair trade and equitable consumption of creative content.

The purpose of presenting such mechanisms in this chapter is not to exhaustively debate their merits or resolve doctrinal implementation issues. Rather, these mechanisms merely illustrate the range of options available to mitigate certain adverse impacts that a market-oriented copyright policy might have. This chapter focuses on examples from Canada that other countries, or the international policymaking community, may find informative.

Importantly, regulatory policy mechanisms to achieve fairer market transactions need not be embedded directly into copyright statutes or the common law. Copyright should not be expected to shoulder the entire load of protecting the public interest in creative industries. It can and should be assessed and reformed as part of a broader package of marketplace framework policies. With better integrated framework policies both protecting and regulating copyright, markets can work better for creators, consumers, and the public interest.

\section{A market-oriented policy framework}

Some frustration with copyright's current inability to fulfil its putative public interest aims stems from the failures of market-based mechanisms (i.e. transactions based on property rights) to achieve cultural as opposed to economic policy objectives. This critique 
of copyright is difficult to overcome, as economic and cultural policies are sometimes irreconcilable. Copyright markets cannot be faulted for failing to promote cultural diversity and producing homogenous blockbusters, if that is what consumers demand. Similarly, one should not necessarily expect cultural policy to prioritise economic or industrial outcomes over preserving heritage or promoting the arts.

This chapter does not purport to resolve tensions between copyright's cultural and economic policy objectives. Rather, the chapter focuses on making copyright markets better at what markets are designed for: generating wealth. While there may be reasons to question whether such instrumental aims are always appropriate, this chapter accepts that economic ends are a (if not 'the') dominant justification for copyright. The chapter, therefore, explains why and how markets can better promote the public interest.

\section{The 'public interest' in copyright markets}

When juxtaposing the amorphous notions of both 'property rights' and 'the public interest', several difficult issues become apparent. In its current incarnation, copyrights - like other property rights - are justified as in the public interest despite their unabashedly private and individualistic nature. In other words, the privatisation of control over expression is seen to promote public policy goals. This is not inconsistent with the values and beliefs of Western liberal democratic societies.

Yet one risk of conceptualising copyright in furtherance of the public interest is that the discourse devolves into purely utilitarian terms, which are not universally accepted. Rights-based perspectives on both property generally and copyright specifically are sometimes controversial but hardly radical. Whether the protection of an individual's natural rights can be encompassed within a public interest framing of copyright as property remains to be seen, perhaps in other chapters of this volume. In one respect, the essence of the rights-based arguments depends on their recognition as inherent and inalienable on an individual level, not the secondary social benefits that accrue to the public at large. Yet, in another respect, the protection of individual rights generally is a matter of public interest, since the stability of society depends on safeguarding such rights. Thus, rightsbased and utilitarian justificatory theories do sometimes align in both theory and practice. 
Regardless, the focus of this chapter is economic utilitarian perspectives on copyright. One reason is that to the extent a market-oriented policy framework is flawed - if policies designed to facilitate market-based transactions are not in the public interest - such concerns are not unique to copyright. Problems apply similarly to copyright and many other public policies.

This chapter accepts the dominant economic framework as appropriate for making copyright policy not because it is the status quo in copyright, but because it is the status quo in liberal democratic societies more generally. My reimagining of copyright in the public interest envisions a regime coexisting within, not divorced from, a much broader patchwork of complementary marketplace framework policies. The public interest in copyright policy specifically is, in my view, not entirely separable from the public interest in economic policy generally.

Of course there are other, additional aims that copyright can and should seek to achieve. But among copyright's multiple aims, I believe that facilitating market transactions, growing creative industries, creating employment opportunities and driving economic activity cannot be ignored.

In a sense, market-oriented mechanisms for making copyright policies in the public interest are a variant of both 'preponderance' and 'common interest' theories discussed in Chapter 1 of this volume. That is because the market is essentially a process for reaching results believed to be in the public interest. A well-functioning market will generate wealth and enhance overall social welfare by facilitating the flow of legal rights to those who value them most. On this theory, markets determine the ultimate allocation of entitlements more than legal or political institutions.

As a general matter, we in liberal democratic societies tend to accept that since market processes are in the public interest, so too are marketdriven outcomes. Society's acceptance of such outcomes is based partly on the theory that the market is an equal-opportunity institution. Any individual is presumed equally capable of using markets to get ahead. In such circumstances, cloaked behind the Rawlsian 'veil of ignorance' about one's lot in life discussed in Chapter 1, the market is a just institution on which to base copyright (or any other economic) policy. 
Yet, the market does not always produce outcomes that, intuitively, seem fair and just to everyone. Sometimes the market seems to fail to further what some people perceive to be the public interest. I accept the public interest is broader than a purely economic paradigm might suggest. There is surely a societal interest in the promotion of markets as a mechanism to generate wealth, but the public interest also comprises things that markets may not do well or at all. For example, markets are notorious for producing inequality. In fact, the unequal distribution of resources is an inevitable feature of free markets. Whether this realisation partly undermines the claim that marketoriented copyright policies promote the public interest is debatable.

I do not claim in this chapter that an unfettered free market is a complete panacea, let alone the only solution to copyright's current crisis. Nor do I claim that copyright markets cause no undesirable consequences. Rather, I suggest that we ought not be too quick to dismiss the potential of copyright as a property right within the broader framework of capitalist systems, which are designed to generate wealth by ensuring that objects of property move to their highest value user/use. Some of the frustration we experience around copyright may arise, at least in part, from trying to make a property rights system do everything and anything including welfare provision, cultural policy, industry policy and more.

One option to make copyright work better in the public interest, therefore, is for copyright as a property right to better do what such rights are meant to do, that is, facilitate market transactions to generate wealth, and then address other aspects of perceived public interest problems through a suite of complementary marketplace framework policies.

And I do believe it is possible to mitigate the market's adverse impacts on, for example, individual creators or consumers. Before proposing three specific strategies to protect the creators and consumers who might be marginalised in an unconstrained copyright marketplace, and thereby protect the public interest more generally, the next part of this chapter explains measures to improve the efficiency of copyright markets. 


\section{The concept of copyright as a property right}

Markets depend on property rights. If property rights are sufficiently exclusive, universal, and transferable, they will form the basis of free markets, and indeed, capitalist economies. ${ }^{1}$ In the absence of prohibitive transaction costs, property rights will be transferred to those who value them the most. ${ }^{2}$ This, according to basic principles of welfare economics, leads to socially optimal outcomes in the aggregate. ${ }^{3}$

These principles form the backbone of the free market economies in which most of us live. And copyright exists as one of many interconnected marketplace framework policies within our entrenched economic structures. Proposals for copyright reform, therefore, might try to harness the power of the market in ways that amplify positive impacts and mitigate adverse effects. That is an aim of this chapter.

Although exchanges of proprietary copyrights are key to the efficient and effective functioning of creative industries, it is dangerous to invoke the rhetoric of property too literally. Like the 'public interest' admirably described by the editors of this volume in their introductory chapter, the concept of 'property' is malleable. Critical literature on the term describes competing approaches and conflicting interpretations. ${ }^{4}$ Property is said by many legal and political philosophers, as well as judges operating in the real world, to be an empty vessel. It means not necessarily the sole and despotic dominion to exclude, ${ }^{5}$ nor a static bundle of incidents of ownership, ${ }^{6}$ but sometimes, it means many different things. ${ }^{7}$ This nominalist perspective on property is not the only one, but it is a powerful one.

1 See Richard A Posner, Economic Analysis of Law (Aspen Law, $7^{\text {th }}$ ed, 2007) 33; Hernando de Soto, The Mystery of Capital (Basic Books, 2000).

2 See Ronald Coase, 'The Problem of Social Cost' (1960) 3 Journal of Law and Economics 1.

3 See Adam Smith, An Inquiry into the Nature and Causes of the Wealth of Nations (W Strahan, 1776).

4 See, for example, Jeremy Waldron, The Right to Private Property (Clarendon Press, 1990); James Harris, Property and Justice (Oxford University Press, 2002).

5 William Blackstone, Commentaries on the laws of England, (Oxford, 1765-1969), Book II Ch 1. 6 Anthony M Honoré, 'Ownership' in Making Law Blind (Clarendon Press, 1987).

7 TC Grey, 'The Disintegration of Property' in J Roland Pennock and JW Chapman (eds), Property: Nomos XXII: Yearbook of the American Society for Political and Legal Philosophy 69 (New York University Press, 1980). 
Some scholars have taken the supposed disintegration of the concept of property rights as an opportunity to promote a unified theoretical framework applicable to both tangible and intellectual property. ${ }^{8}$ I would agree that intellectual property policy is appropriately guided by general principles of property law, but without suggesting that we can directly transpose tangible property rules to solve intellectual property issues, or ignore crucial differences between tangible and ideational resources.

Recognising that the concept of property rights underlying the modern copyright system is itself open to interpretation and redefinition triggers the realisation that we can reimagine copyright too. We need not jettison the principles of property rights that animate copyright in its present form in order to redesign the conceptual and doctrinal features of copyright that make it so dysfunctional in many contexts.

The pragmatic question that shapes this chapter is how far from the existing economic and political structures to stray in reconceptualising copyright. Rather than entirely reimagining copyright outside the framework of liberal capitalist markets - an exercise which does have great value but is not the aim of this particular chapter - the following sections explore how copyright could be designed within the presently dominant political economic paradigm. The objective is to enquire what the structure of copyright should look like if it were to achieve its putative purposes within a market economy.

\section{The structure of copyright's bundle of rights}

The current doctrinal structure - under public international laws as well as corresponding domestic laws - of the bundle of copyrights (and/or neighbouring rights) is problematic from a market-oriented perspective. Economic justificatory theories that might support the notion that copyright promotes the public interest (as a wealthgenerating market mechanism) depend upon the absence of transaction costs that the structure of copyrights as a fragmented and layered bundle of rights exacerbate rather than ameliorate. If copyright truly promoted the public interest as an effective marketplace framework

8 Richard A Epstein, 'The Disintegration of Intellectual Property? A Classic Liberal Response to a Premature Obituary' (2010) 62(2) Stanford Law Review 455. 
policy, it would not be a fragmented and/or layered bundle of rights, but rather a more coherent, stable, and simple allocation of an exclusive entitlement.

Copyright is not currently structured as a grant of a unitary right, an indivisible whole, but rather of a series of exclusive but limited rights in a work to do specific things. This series, or bundle, of rights may be dealt with as a whole or individually. And just as copyright itself is alienable - it may be assigned or licensed exclusively or nonexclusively - so too may each fragment of the bundle be independently alienable. In this way, a single work may boast multiple 'owners', each independently exercising their rights to exploit their interests in the work. Copyright ownership, by design, may be fragmented.

This leads to numerous challenges in the exploitation of copyrightprotected works, including royalty stacking: the layering of multiple payments for permission to use copyright-protected work. In the same work, there are rights of reproduction, performance, distribution, making available and perhaps more. This fragmentation of rights may have made sense in an analogue era, but it is becoming increasingly dysfunctional for digital content. The same single activity (e.g. webcasting) may implicate numerous different rights fragments, with royalties often payable to the same entity (e.g. a composer) through different market channels. This system screams inefficiency, without even considering territorial or temporal issues. Royalty stacking can happen through multiple administrative tariffs, redundant collective licensing structures, or overlapping individual license agreements.

These royalty stacking problems increase uncertainty over the availability of works as potential licensees must identify multiple right holders entitled to participate in revenue streams associated with the exploitation of the work. Similarly, royalty stacking increases transaction costs associated with such exploitation. Royalty stacking also potentially increases the absolute value of wealth transfers to right holders as each holder of an exclusive right is positioned to leverage that exclusivity in an inefficient system.

To this complex framework most copyright laws add further layers of property holders: owners of neighbouring rights. These stakeholders obtain rights not for their contribution to the authoring of creative works, but for contributions to the propagation and dissemination 
of such works. In an earlier iteration of copyright, these service providers' role in copyright's ecosystem benefited from the sphere of exclusivity afforded the copyright owner, but enjoyed no rights independent of the copyright owner. The appearance of neighbouring rights greatly complicated the copyright industrial ecosystem.

To further complicate matters, neighbouring rights holders may also fragment their bundle of rights. Like copyright, fragments of the neighbouring rights bundle are assignable and licensable on an exclusive or non-exclusive basis. Downstream users and creators now have to negotiate multiple potential claimants, claiming rights in distinct artefacts, to make use of and build on prior works.

The end result is that users and creators dealing with disseminated copies of works often have to transact with multiple right holders exercising numerous classes of rights, with nothing in this structure guaranteeing a common understanding of how to exploit those rights.

\section{Streamlining rights to smooth transactions ${ }^{9}$}

One of the main complaints about the current doctrinal structure of copyright is that it adds costs and complicates transactions. Adding costs is not a policy problem per se; if those costs are justified on a principled basis, imposing them simply transfers wealth from one party to another.

Transactional inefficiencies, uncertainties and complications are more serious challenges, however. These can undermine functioning of the market for copyright-protected content, inhibit the introduction of innovative products and services, and cause economic losses to all parties involved. To understand how, we can consider the fundamental economic theories underlying all property rights, including intellectual property rights.

9 Jeremy de Beer, 'Copyright Royalty Stacking' in Michael Geist (ed), The Copyright Pentalogy: How the Supreme Court of Canada Shook the Foundations of Canadian Copyright Law (University of Ottawa Press, 2013) 335. 


\section{The economic problem with copyright royalty stacking}

As introduced earlier in the chapter, Judge Richard Posner, a godfather of law and economics scholarship, points out that property law is most efficient when rights are exclusive, universal and transferable. ${ }^{10}$ The last of these features is most relevant to royalty stacking. In an enormously influential and widely cited article, economist Ronald Coase explained how, in a world without transaction costs, rights will be exchanged in markets that efficiently allocate entitlements to those who value them the most. ${ }^{11}$ This concept is central to welfare economics, and a primary reason that people believe intellectual property protection is capable of driving economic growth.

Although rarely articulated as such, the Coase theorem underpins the utilitarian concept of intellectual property rights as incentives. Intellectual property provides incentives to invest time, effort and money into intellectual endeavours because rights can be exploited in the market to make profit. Take away market transactions and you are left with a purely psychological theory of incentives or deontological theory of intellectual property protection.

Since Coase's path-breaking article was published in 1960, scholars have sought to better understand the factors that interfere with efficient bargaining. One such factor is the fragmentation and/or layering of rights. Michael Heller identified the problem of property fragmentation in a seminal article published in the Harvard Law Review in $1998 .{ }^{12} \mathrm{He}$ called this the 'tragedy of the anticommons,' mirroring Garrett Hardin's famous parable of the 'tragedy of the commons' that had been published 40 years earlier. ${ }^{13}$ Hardin initially presented private property rights as a solution to the tragic overuse of resources that would occur in a world of open access. Heller did not dispute Hardin's claim, but countered that private property can also be a problem. Too much property is as inefficient as too little.

10 Posner, above $\mathrm{n} 1,33$.

11 Coase, above n 2.

12 Michael A Heller, 'The Tragedy of the Anticommons: Property in Transition from Marx to Markets' (1998) 111(3) Harvard Law Review 621.

13 Garrett Hardin, 'The Tragedy of the Commons' (1968) 162 (3859) Science 1243. 
He and Rebecca Eisenberg applied this insight to intellectual property rights specifically: 'In theory,' they wrote, 'in a world of costless transactions, people could always avoid commons or anticommons tragedies by trading their rights. In practice, however, avoiding tragedy requires overcoming transaction costs ... Once an anticommons emerges, collecting rights into usable private property is often brutal and slow.' ${ }^{14}$ This phenomenon has also been discussed as a 'thicket, a dense web of overlapping intellectual property rights that a company must hack its way through in order to actually commercialize new technology.' ${ }^{15}$ Mark Lemley and Carl Shapiro have also studied the interconnected problems of patent holdups and royalty stacking when a patent covers one important component of a complex product. ${ }^{16}$

Thickets are not just a patent problem; such concerns apply to copyright as well. Daniel Gervais and Alana Maurushat have described, for example, the fragmentation of collectively administered copyright in Canada, explaining how the rights contained in section 3 [of Canada's Copyright Act] are no longer useful in mapping out the real world' ${ }^{17}$ While their focus is on the practical rather than theoretical problems of fragmentation, they effectively highlight the complexities of copyright licensing transactions.

Scholars such as Epstein are right to analogise tangible and intellectual property, but wrong to suggest that fragmentation is not a problem in either context. While Esptein acknowledges, for example, that 'the key relationship thus asks whether the gains from voluntary fragmentation exceed the added transactions costs of running the system,' he ignores the fact that in copyright the lack of recordation or adequate ownership tracking devices is a major problem. ${ }^{18}$ If proposals for copyright registration and tracking requirements,

14 Michael A Heller and Rebecca S Eisenberg, 'Can Patents Deter Innovation? The Anticommons in Biomedical Research' (1998) 280 (5364) Science 698. See also Michael A Heller, The Gridlock Economy: How Too Much Ownership Wrecks Markets, Stops Innovation, and Costs Lives (Basic Books, 2008).

15 Carl Shapiro, 'Navigating the Patent Thicket: Cross Licences, Patent Pools and Standard Setting' in Adam B Jaffe, Josh Lerner and Scott Stern (eds), Innovation Policy and the Economy (MIT Press, 2011) 120.

16 Mark A Lemley and Carl Shapiro, 'Patent Holdup and Royalty Stacking' (2007) 85 Texas Law Review 1991.

17 Daniel J Gervais and Alana Maurushat, 'Fragmented Copyright, Fragmented Management: Proposals to Defrag Copyright Management' (2003) 2(1) Canadian Journal of Law \& Technology 20. 18 Epstein, above n 8, 472. 
laid out in other chapters of this book, were to be accepted, the complexity of copyright's fragmented and layered bundles of rights would be of less concern. In the absence of such alternative solutions, however, fragmentation and layering seriously frustrate free market transactions.

The Supreme Court of Canada has also acknowledged that too much copyright protection can cause adverse consequences, ruling in the Théberge case: 'In crassly economic terms it would be as inefficient to overcompensate artists and authors for the right of reproduction as it would be self-defeating to undercompensate them. ${ }^{19}$ While the Supreme Court did not elaborate in Théberge on the reasons that overcompensation is inefficient (which may be related to transaction costs or other factors), in its more recent jurisprudence it has taken an important step towards a legal interpretation of the Copyright Act that reduces royalty stacking. ${ }^{20}$

One argument to counter concerns over transaction costs is that the legislation in most countries contains explicit statutory recognition that right holders may carve up copyrights in any manner they please. Subsection 13(4) of Canada's Copyright Act, for example, states clearly:

The owner of the copyright in any work may assign the right, either wholly or partially, and either generally or subject to limitations relating to territory, medium or sector of the market or other limitations relating to the scope of the assignment, and either for the whole term of the copyright or for any other part thereof, and may grant any interest in the right by licence ...

However, it is important to distinguish particular licensing practices from established legal rights. Contracts may contain a wide variety of unique clauses on payments or permissions enforceable against specific parties, that is, in personam rights. But courts need not compound the legal complexity by reinforcing the fragmentation of copyrights in rem, enforceable against anyone.

19 Théberge v Galérie d'Art du Petit Champlain Inc, [2002] 210 DLR (4 $\left.{ }^{\text {th }}\right)$ 385, 31 (Supreme Court of Canada).

20 Entertainment Software Association v Society of Composers, Authors and Music Publishers of Canada, [2012] 2 SCR 231. 
In real property law, the notion that rights should not be fragmented beyond a stable set of fixed entitlements is known as the numerus clausus principle. Its origins lie in the civil law system, but the label has also been applied to similar common law concepts. ${ }^{21}$ As applied in the well-known common law case of Keppell $v$ Bailey, the principle holds that private parties cannot through property transactions or licensing practices create new incidents of ownership. ${ }^{22}$ Parties may generally structure contractual relationships however they wish, but cannot by doing so transform the nature of the underlying property rights vis-à-vis third parties or the general public.

Merrill and Smith note that the numerus clausus principle applies not only to real property, but is also reflected in other areas of property law, including intellectual property. ${ }^{23}$ They remark that the numerus clausus is 'an extremely important qualification on the principle of freedom of contract - a principle widely regarded by law and economics scholars as promoting the efficient allocation of resources' ${ }^{24}$ It is particularly useful for limiting adverse effects of excessive fragmentation, that is, an anticommons. ${ }^{25}$ While Merrill and Smith's work centres on the limited forms that intellectual property rights in general may take, other scholars have explained how the same principles should prevent fragmentation within intellectual property rights, such as copyrights. ${ }^{26}$ The concept has been applied most specifically to digital copyright cases.

The numerus clausus serves several important functions required equally, if not more, for intellectual property than for real property. It facilitates transferability of rights, increases certainty of transactions, aids identification of owners, and more. Bruce Ziff points to another rationale for the numerus clausus principle: '[I]mpediments to the termination of property rights suggests the need for caution

21 Bruce Ziff, 'The Irreversibility of Commodification' (2005) 16(283) Stellenbosch Law Review 283.

22 Keppell $v$ Bailey (1834) 2 My \& K 517.

23 Thomas W Merrill and Henry E Smith, 'Optimal Standardization in the Law of Property: The Numerus Clausus Principle' (2000) 110(1) Yale Law Journal 4 [Merrill and Smith].

24 Ibid 5 .

25 Ibid 6.

26 Christina Mulligan, 'A Numerus Clausus Principle for Intellectual Property' (2012) 80 Tennessee Law Review 235; Enrico Baffi, 'The Anticommons and the Problem of the Numerus Clausus of Property Rights' (19 October 2007, unpublished) < papers.ssrn.com/sol3/papers. cfm?abstract_id $=1023153>$. 
in their initial recognition, because doctrinal mistakes cannot easily be corrected. ${ }^{27}$ In other words, once a new right is recognised, it is very difficult to reverse. The one-way ratchet of intellectual property dealings that fragment existing rights or add new ones is a well-documented problem. ${ }^{28}$ Policymakers as well as judges should be reluctant to contribute to this phenomenon by recognising new fragments of copyright.

So, based on the numerus clausus principle, even if it is true most copyright systems permit owners to structure licensing and administration in creative ways, it does not follow that courts should recognise such arrangements as creating or reinforcing proprietary in rem entitlements.

A question remains what more streamlined rights could or should look like if unconstrained by treaty and history. At the very least, copyright's bundle of rights would not be more complicated than it currently is. Far preferably, copyright would be much simpler.

One might imagine, for example, a unitary 'use' right, that is, a basic economic right to exploit a work's value. The right to use a work could take the place of the many more specific incidents of copyright ownership that have been appended to copyright over time, like layers of papier-mâché, to respond to various technological developments or to merely placate special interests. Rather than separate and distinct rights to reproduce, perform, publish or exploit a work in myriad other ways, a pure use right might better suit copyright's function as marketplace framework policy.

Simplifying copyright as such could eliminate many of the uncertainties and controversies surrounding the boundaries between particular rights - reproduction, performance, publication, etc. - which add transaction costs impeding market transactions. Although the price of a licence for the right to use a work would not necessarily be lower

27 Bruce Ziff, 'Yet Another Function for the Numerus Clasus Principle of Property Rights, and a Useful One at That' (19 March 2012) < papers.ssrn.com/sol3/papers.cfm?abstract_id=2026088>, 1.

28 For example, see Susan Sell, 'The Global IP Upward Ratchet, Anti-Counterfeiting and Piracy Enforcement Efforts: The State of Play' (Research Paper 15, Program on Information Justice and Intellectual Property American University Washington College of Law, Washington, DC, 2010). See also Peter Drahos, 'The Global Ratchet for Intellectual Property Rights: Why It Fails as Policy and What Should Be Done About It' (2003). 
than the aggregate of the licences currently required for multiple copyright fragments, these licences would likely be faster and simpler to acquire. As well as reducing royalty stacking, it would eliminate the potential holdout problem that exists where multiple permissions from different copyright owners are required.

While a unitary right would be divisible by licence, such contracts would not create rights in rem. Licences might be exclusive or nonexclusive; this need not be prescribed but would be determined by economic conditions and market forces.

Perhaps the most interesting question is not what a use right is defined to be, but whether and how a use right is defined at all. One option is to embed a detailed definition within international treaties and/or national legislation. Instinctively, this is appealing from an economic perspective as it would arguably increase legal certainty and, therefore, reduce transaction costs. On the other hand, a rigidly defined use right might also be so technologically or contextually specific that it creates instabilities as circumstances change over time. A preferable option, perhaps less predictable but not necessarily less efficient over time, would be a right subject to judicial interpretation and application. Judges in many countries have proven capable of providing clear guidance on the scope of copyright, as well as other important matters of economic policy.

Also regarding the scope of a possible unitary use right, there is no necessary reason that the current fair use/dealing provisions or other limitations and exceptions need change. Nor would the principles of exhaustion that govern the boundaries between intellectual and tangible property rights be redrawn. Use may include the first sale of a work to the public.

Fully specifying the contours of such a right in the space of this chapter would be susceptible to premature and unnecessary criticism. My modest aim here is to promote the concept, not the specifics, of simpler, purer rights that are more compatible with the marketbased justifications that rightly animate copyright policy. 


\section{Inequality as an implication of structural simplification}

Structuring copyright as a unitary and indivisible 'use' right may not be easy to implement, given existing legal constraints and vested commercial interests. But, based on sound economic theory, ensuring the copyright's bundle of entitlements stays as streamlined as possible will help to facilitate market transactions and increase the size of creative industries. The simpler (though not necessarily cheaper) it is for businesses to buy and resell copyright-protected content, the faster the market for innovative products and services will develop, and the larger it will grow. This is desirable for consumers, who will have a wider range of choice. This is also desirable for creators, who will have more commercial paths to the market, more competition from intermediaries leading to higher prices, and increased consumer demand for the creative content they sell.

While all stakeholders would benefit from streamlined system of copyright transactions, it is an inherent feature of the market that the benefits are unlikely to be distributed equally. Free markets are not known for their ability to achieve distributive justice. We know from both theory and experience that copyright markets tend to concentrate power and wealth in the hands of intermediaries.

At one time, the most powerful intermediaries tended to be the book publishers, record labels, movie studios, or other entities that mediated between individual creators and the mass market of consumers. More recently, we have witnessed a shift in wealth and market power away from these conventional intermediaries towards the technology companies that provide platforms through which consumers access content. The creative industries' newest power brokers include hardware manufacturers, online retailers and search engines. This shift from old media gatekeepers has been praised for opening up our culture, ${ }^{29}$ and criticised for giving a free ride to new information oligopolies. ${ }^{30}$

29 Lawrence Lessig, Free Culture: How Big Media Uses Technology and the Law to Lock Down Culture and Control Creativity (Penguin Press, 2004).

30 Robert Levine, Free Ride: How Digital Parasites are Killing the Culture Business, and How the Cultural Business Can Fight Back (Anchor Books, 2011). 
In this tug-of-war between industrial intermediaries, the interests of individual creators as well as individual consumers are easily neglected. Streamlining the rights clearance process in order to make market transactions more efficient admittedly risks exacerbating the inequalities of the current system. Both creators and consumers could become increasingly vulnerable and marginalised, contrary to many people's intuitive sense of distributive justice and therefore 'the public interest'.

\section{Protecting creators, consumers and the public}

The final section of this chapter points out three possible ways to mitigate potential distributive injustices of the free market. First, collective bargaining can bolster the contractual negotiating hand of individual creators to reduce power asymmetries in creative industries. Second, class action litigation proceedings can be used to enforce the common interests of those who suffer individually small but aggregately significant economic or other harms. Third, certified branding schemes can be used as a market signal to harness the commercial power of ethical consumers who want to fairly compensate creators.

These protections, notably, may involve marketplace framework policies external to copyright itself. Internal structural reforms to copyright can be extremely valuable when reorienting copyright to better serve the public interest. Within the free market paradigm promoted in this chapter, a recordation system is among the most crucial changes long overdue. Other chapters in this volume mention or deal in depth with the rationale for registration and tracking mechanisms, which I strongly endorse and are fully consistent with the recommendations in this chapter.

The value added by the discussion below is to suggest that promoting the public interest is a job that ought not be left to copyright alone. A public interest oriented copyright system necessarily exists in the context of broader marketplace framework regulation, which provide 
checks and balances against abuses of market power. Before discussing mechanisms to address creators' rights, it is useful to explain how users' rights fit within a free market framework for copyright policymaking.

\section{Copyright markets and the recognition of users' rights}

One of the interesting implications of the conceptual framework adopted for rethinking copyright as a property right in the public interest concerns users' rights. In the natural rights theory justifying creators' rights, it is challenging to find room for, or worry about, the interests of copyright users. While scholars are starting to articulate strong non-economic arguments for limits on authors' rights, ${ }^{31}$ support for users' rights is widely believed to depend upon a utilitarian calculus that suggests they cause less harm than good. Reaching that conclusion arguably becomes more difficult the less clear and predictable users' rights are.

There is at first glance some tension between, on one hand, the fair and flexible nature of users' rights originating in principles of equity and, on the other hand, the stable and certain allocation of entitlements that facilitates free market transactions. In this context, user rights that exacerbate uncertainty and create transaction costs ought to be discouraged, or avoided altogether.

On examination, this concern is real, but surmountable. Respecting users' rights within this framework requires understanding 'the public interest' as more than bare utilitarian principles might imply. The public interest in recognising users' rights is to be found in the underlying values these rights promote. A user's right of fair dealing, explains Drassinower, 'is to be understood and deployed not negatively, as a mere exception, but rather positively, as a user right integral to copyright law.' ${ }^{32}$

Although the economic logic and political rhetoric of property has powerful connotations about the supremacy of those rights over other interests, there is nothing extraordinary in recognising that all property rights are somehow limited in time, space, or scope.

31 See e.g. Abraham Drassinower, What's Wrong with Copying? (Harvard University Press, 2015).

32 Abraham Drassinower, 'Taking User Rights Seriously' in Michael Geist (ed), In the Public Interest: The Future of Canadian Copyright Law (Irwin Law, 2005) 462, 467. 
Often, property rights yield when confronted by equally or more weighty rights, such as rights of expression or access to information, as examples. Counterbalancing is driven both by individual rights and social values. ${ }^{33}$

Therefore, the analysis in this chapter does not pre-empt the recognition of users' rights on account of the systematic inefficiencies that might be created by doing so. Rather, this chapter's analysis suggests that if copyright's proprietary nature is to be counterbalanced, users' rights cannot be seen merely to serve public interests as well. Users' rights must be understood to represent fundamental rights as or more important than copyrights in certain circumstances.

As an even higher principle, authors' and users' rights are inseparable from each other, and both equally integral to the fabric of an effective marketplace framework policy. The market could not function without appropriate consumer protection mechanisms in place. And consumer protection mechanisms are not merely an inconvenient limit on owner's rights, but rather equally important in setting public policies and negotiating private transactions.

The principle underpinning user rights is manifested not only within copyright limitations and exceptions, but also through market mechanisms external to copyright, including consumer protection laws. Rules that limit the scope of copyright protection by reference to other owners' tangible property rights, through the doctrine of exhaustion, further reinforce users' rights with basic principles of property law. ${ }^{34}$

\section{Fairer contracts through collective bargaining}

From an economic perspective, markets depend as much on contracts as they do on property rights. Contracts are the mechanisms through which property rights are transferred to the parties that value them most. Pareto efficient contractual exchanges of rights - trades that leave

33 Jeremy Waldron, 'From Authors to Copiers: Individual Rights and Social Values in Intellectual Property' (1992) 68 Chicago-Kent Law Review 841.

34 Jeremy de Beer and Robert J Tomkowicz, 'Exhaustion of Intellectual Property Rights in Canada' (2009) 25 Canadian Intellectual Property Review 3. 
at least one party better off without making anyone worse off ${ }^{35}$ - are what the current copyright system is designed to promote. However, Pareto optimal transactions do not necessarily (and frequently do not) increase either equality or overall social welfare. ${ }^{36}$

If the public interest is defined within a theoretical framework modelled on Rawls' theory of justice, as discussed in the introduction to this volume, then equality is a major concern that the free market alone cannot solve. Limiting the accumulation of wealth and power by intermediaries in creative industries may require putting regulatory limits on their freedom to contract or finding other ways to adjust the balance of negotiating power. Existing approaches within copyright are theoretically and practically inadequate. ${ }^{37}$

There are two ways in which the freedom of contract may be constrained or contractual bargaining power recalibrated: by embedding limitations on contracts within copyright itself, or by leveraging framework mechanisms from areas other than copyright. A comparison and consideration of both mechanisms suggests that more generally applicable approaches are preferable.

One example of a limitation, internal to copyright, that exists in some jurisdictions concerns creator's rights of reversion. In Canada, for example, copyright in works reverts back to an author's estate 25 years after the author's death. (Technically, the law is that grants or licences become void at that time, but the practical effect is the same. $)^{38}$ The author's right of reversion in Canada traces to the similar provision in the laws of the United Kingdom, from which Canadian law derives. It is similar in principle to author's termination rights in the United States.

Reversionary rights are putatively designed to provide protection for authors against bad deals. However, they are ineffective in most circumstances at doing so. First, rights revert not to authors but rather to their estates or heirs, a result that might seem nice for those heirs

35 Vilfredo Pareto, Manual of Political Economy (Ann S Schwier trans, Augustus M Kelley, 1972).

36 Amartya Sen, Markets and Freedoms: Achievements and Limitations of the Market Mechanism in Promoting Individual Freedoms (1993) 45(4) Oxford Economic Papers 518.

37 See generally Giuseppina D'Agostino, Copyright, Contracts, Creators: New Media, New Rules (Edward Elgar, 2010).

38 Copyright Act, RSC 1985, c C-42, s 14(1). 
but lacks any justification related to instrumental or natural property rights. Second, the practical impact of reversionary rights is to create confusion and uncertainty in the marketplace for no good reason.

From the perspective of law and economics adopted in this chapter, the problems outweigh the benefits. ${ }^{39}$ That conclusion is not surprising since, according to general property theory, rights of termination and reversion are undoubtedly a form of restraint on alienation not normally encouraged in the design of efficient property rights systems. Many British Commonwealth countries have repealed the equivalent provisions in their laws, and repeal has been recommended in Canada too. ${ }^{40}$

The purpose of discussing reversion rights here is not to conduct an exhaustive analysis of that particular mechanism for protecting authors' rights vis-à-vis intermediaries. Rather, it exemplifies the problem that arises when policymakers expect a single market-oriented instrument to do many things at once. If copyright is designed as a property right in order to promote efficient market transactions, then burdening the rights with the complex possibility of termination or reversion is unwise. In practice, this ostensible creator-protection mechanism fails to protect anyone, but instead risks frustrating the market completely.

A better approach is to invoke protections that are effectively used elsewhere in the legal system to address inequities caused by the concentration of market power. One example is collective bargaining by parties who are vulnerable to exploitation.

Bargaining collectively for better contractual terms is a strategy that has been used effectively, for example, by visual artists in Canada. A legislative framework modelled on general principles of labour law exists in Canada to protect artists against exploitation. ${ }^{41}$ It clearly states the policy purposes of recognising the cultural, social, economic and political importance of artists, and establishes a framework to ensure freedom of artists' expression, association and organisation to negotiate and protect artists' interests.

39 Kate Darling, Occupy Copyright: A Law \& Economics Analysis of U.S. Author Termination Rights (1 March 2014) Social Science Review Network <ssrn.com/abstract $=2422672>$.

40 Bob Tarantino, 'Long Time Coming: Copyright Reversionary Interests in Canada' (2013) 375 Développements récents en droit de la propriété intellectuelle 1.

41 Status of the Artist Act, SC 1992, c 33. 
A description of ongoing negotiations between visual artists and an art gallery helps demonstrate the potential of the collective bargaining mechanism. In Canada, two organisations certified by the governing labour tribunal ${ }^{42}$ to represent visual artists negotiated with the National Gallery of Canada over minimum exhibition fees to be paid by the gallery for exhibiting artworks. While an argument was made that this negotiation process could conflict with the Copyright Board of Canada's royalty-setting procedures involving users and collective societies, the Supreme Court of Canada held there was no such conflict. ${ }^{43}$ Legally, the negotiation of these minimum royalty rates does not bind collective societies. The labour law procedures, rather, protect the interests of artists who have not assigned their rights to a collective society.

Practically, the collective bargaining mechanisms available through labour laws complement the collective management mechanisms available through copyright laws. Artists have more choice in administering their rights, which competition should lead to more efficiencies in and better terms with intermediary collective societies. The negotiation mechanisms of labour law also help to establish fairer industry practices that should become benchmarks against which licences from collective societies can be measured.

Currently, in Canada, the power of organisations to bargain on behalf of authors is confined to negotiations with federally governed entities. This limitation is a corollary of Canadian federalism, which allocates responsibility for most labour law issues to the provincial level. This chapter does not address whether a similar approach would be desirable or feasible at the interprovincial or international level. Rather, it raises the example of collective bargaining as a way in which author's rights can be protected in the public interest other than via paternalistic approaches within copyright law, such as termination and reversion rights.

There is no doubt that collective bargaining procedures constrain the free market by empowering creators and limiting the control of creative industry intermediaries. From a purely libertarian perspective,

42 At the time, a specialised tribunal called the Status of the Artists Tribunal, but now the same Canada Industrial Relations Board that handles other federal labour matters.

43 Canadian Artists' Representation v National Gallery of Canada [2014] SCC 42 (14 May 2014). 
this may not be ideal. However, a market-oriented copyright system can be structured to facilitate transactions while at the same time other framework policies help to promote fair and equitable treatment of persons who might otherwise be marginalised by uninhibited free market transactions.

\section{Class proceedings to enforce common interests}

As the discussion of collective bargaining demonstrates, individual creators may be disempowered by free market approaches to copyright policy. While this outcome is not inconsistent with the theory or practice of welfare-maximising liberal economic policy generally, it can create distributive inequalities that sit uneasily with many people's sense of justice. A series of cases brought through the Canadian courts as class proceedings shows how individual copyright owners have been able to assert their rights and reclaim a degree of market power.

In one important case, Robertson $v$ Thomson Corp, freelance authors were able to stop the reproduction in electronic databases of contributions they had made to newspapers. ${ }^{44}$ The newspaper publisher had digitised decades' worth of content, and was selling licences to access databases containing works authored by its own employees as well as freelance writers.

The precedent established in the Robertson case helped to empower freelance authors. Although, admittedly, that particular decision failed to change dominant industry practices (newspaper publishers are now more explicit in the assignment or license agreements they obtain from authors), it did provide important recognition of authors' rights as well as financial compensation. The case also inspired other copyright owners to take action protecting their rights. Also in Canada, lawyers brought class proceedings against the operators of legal databases that reproduced and sold access to court pleadings drafted by lawyers, which are copyright-protected works. After a lengthy process of litigation and negotiation, the dispute was settled..$^{45}$

44 Robertson $v$ Thomson Corp [2006] 2 SCR 363 (Supreme Court of Canada).

45 Waldman $v$ Thomson Reuters Canada Limited [2016] ONCA 2622 (28 April 2016). 
Arguably, these kinds of cases are only feasible as class proceedings. It would be extremely difficult for any individual freelancer to commence, let alone complete, litigation against a publisher seeking to enforce her copyrights in a small number of articles. The value of each alleged copyright infringement would not be significant enough to warrant the cost and complexity of a lawsuit.

Class action procedures, however, grant one plaintiff standing to represent a larger group of similarly situated would-be plaintiffs. In order to be certified by a court as a class proceeding, there must be a cause of action that involves common issues, among an identifiable class of two or more persons, represented by a suitable plaintiff or defendant, for which a class proceeding is the preferable procedure to resolve. ${ }^{46}$

Enabling access to justice is one of the key purposes of class proceedings. Judicial economy is another. A third reason for class actions is behaviour modification and the deterrence of wrongdoing. ${ }^{47}$ All of these purposes are well aligned with the goal of addressing power imbalances that can be created by copyright markets. Class proceedings can help to mitigate some of the potential inequities that might result from further streamlining market transactions.

The purpose of class proceedings is somewhat similar to the rationale for the original collecting societies that emerged around the turn of the 20th century: protecting and administering the rights of authors more efficiently through collective action than is possible individually. Class proceedings actually have numerous advantages over collecting societies, including more flexible procedural mechanisms and more effective remedial powers. It is not surprising, therefore, that class proceedings are becoming increasingly common mechanisms for protecting individual creator's rights.

Class proceedings have also helped protect authors against creative industry intermediaries other than publishers. In the case of Northey $v$ Sony Music, individual songwriters and music publishers brought

46 See, for example, Class Proceedings Act, SO 1992, Ch 6, s 5.

47 Hollick $v$ Toronto [2001] 3 SCR 158 (Supreme Court of Canada). 
an action against the major record labels for failing to pay proper royalties. ${ }^{48}$ The judicially approved settlement required record labels to distribute almost $\$ 50$ million they had failed to pay over many years.

Canada is not the only place where class proceedings are being used to protect the rights of individual creators. In the United States, musicians have sued over the refusal of satellite radio companies to pay royalties on certain old songs. ${ }^{49}$ Several class actions have been brought against digital music providers, such as Spotify.

The Google Books case in the United States, Author's Guild $v$ Google Inc, is a hybrid example of class proceedings brought to protect both the rights of individual authors and powerful publishing companies against an equally or even more powerful technology company. ${ }^{50}$ Whether one agrees with the plaintiffs or defendant, the case demonstrates how power asymmetries in the copyright industry are being adjusted by procedural mechanisms outside of copyright itself.

Bringing disputes into a judicial forum where both parties are equal before the courts is, presumably, preferable to leaving one or the other party vulnerable to the power structures of the free market. The supervisory jurisdiction, procedural flexibilities, and remedial powers of the courts should in principle lead to fairer outcomes (including perhaps fairer negotiated settlements) than would have resulted in the absence of a class proceeding.

Finally, the power of class proceedings have been leveraged by consumers to protect users' rights in the creative industries. When one of the major record labels several years ago included surreptitious digital rights management software on compact discs, violating consumers' privacy rights and causing security vulnerabilities, a class

48 See Craig Northey $v$ Sony Music Entertainment Canada Inc et al [2011] ONSC CV 08000360651 (27 March 2011); media coverage in Christine Dobby, 'Judge approves settlement in music royalties class action' Financial Post (Toronto) 30 May 2011; and settlement at $<$ harrisonpensa. com/expertise/class-actions/list-of-cases/pending-lists-new $>$.

49 'The Turtles v Sirius Conformed and filed Complaint' (1 August 2013) <www.scribd.com/ doc/157678779/The-Turtles-v-Sirius-Comformed-and-Filed-Complaint-3>; see also 'The United States against Pandora' (17 April 2014) <www.scribd.com/doc/218883012/Pandora-ComplaintFiled>; See also 'Sirius XM Radio' (11 September 2013) <www.hollywoodreporter.com/sites/ default/files/custom/Documents/ESQ/bc520981.pdf $>$.

50 Jeremy de Beer, 'New Forms of Governance for Digital Orphans' in Mira Burri and Thomas Cottier (eds), Trade Governance in the Digital Age (Cambridge University Press, 2010), 344. 
action lawsuit was used to enforce users' rights. ${ }^{51}$ Most recently, class proceedings were successfully brought against the music publishing company that claims to own and collect royalties for the song, 'Happy Birthday' ${ }^{.52}$ The lawsuit, which would have been uneconomical as an individual action, sought to stop dubious copyright claims and thus protect the public domain.

This subsection of the chapter has shown that, to the extent streamlining market transactions leads to the concentration of wealth and market power in the hands of intermediaries, class proceedings can be a useful mechanism to remedy power imbalances. Policymakers need not expect procedures internal to copyright, such as collective administration schemes, to shoulder the entire load. Class proceedings can enhance creators' access to justice, and help to modify the behaviour of intermediaries who might otherwise abuse market power.

\section{Certification schemes to harness public support}

The final mechanism for addressing inequities in copyright markets discussed in this chapter is the adoption of certification schemes. Following several years of groundwork, proposals for 'fair trade' branding strategies in the music industry have begun to gain traction. Through certification and branding schemes, creators can harness the power of the market to protect their interests. If consumers demand, and are willing to pay for, creative works that fairly remunerate authors, market intermediaries will be pressured to adjust their practices to satisfy consumer demand.

While the idea of a 'fair trade music' system has only recently received widespread attention, ${ }^{53}$ the idea took several years to come to fruition. First developed in 2009, the concept was based on the belief that consumers want creators to be treated fairly:

51 Jeremy de Beer, 'How Restrictive Terms and Technologies Backfired on Sony BMG' (2006) 6(12) Internet \& E-Commerce Law in Canada 93.

52 Rupa Marya $v$ Warner/Chappell Music Inc, Docket 2:13cv04460 (United States District Court Central District of California).

53 International Council of Creators of Music (CIAM), Creators Call for Fairer Digital Revenues Distribution Model, Inspired by the Fair Trade Movement (24 October 2014) CISAC < cisac.org/ CisacPortal/consultArticle.do?id=1871>. 
Fair Trade Music's vision is a global music business in which marketbased mechanisms facilitate more respect for the rights of creators, consumers and the communities to which they all belong. The idea is to certify the actions of influential parties in the music business as being compliant with a set of core values - dignity, equity, respect, and transparency - that define fair practice. Parties whose practices espouse these values can leverage certification into a powerful branding strategy that turns associated goodwill into a competitive advantage in the music market. The result will be socially responsible commercial success. ${ }^{54}$

The initial proposal for a five-step certification process was based on the successful experiences in other fields, ranging from agriculture to textiles. ${ }^{55}$

In the years since the idea was proposed, some modest but important steps were independently taken towards implementation. A local group of musicians in Portland, Oregon established 'Fair Trade Music PDX', ${ }^{56}$ certifying live music venues that meet certain criteria. Facebook and Twitter were used to promote the concept. ${ }^{57}$ The concept of 'fair trade copyright' also attracted scholarly attention, although proposing a donation system instead of a profit-driven branding scheme. ${ }^{58}$ More momentum began building when the Songwriters Association of Canada (SAC) publicly disclosed the idea in 2013. ${ }^{59}$

The contours of a fair trade music initiative are still evolving. But the core principles of inclusiveness, fairness, and transparency remain true to the initial vision. Details of the concept and clarifications

54 Jeremy de Beer and S Javed, 'Changing Tune: A Proposal for Fair Trade Music' (October 2009, unpublished). See also Helienne Linvall, 'Could sites such as Muzu and Spotify help musicians get their fair share?', The Guardian (online), 23 April 2009 <www.theguardian.com/ music/musicblog/2009/apr/23/downloads-spotify-muzu-fair-trade>.

55 See Graeme Auld, Constructing Private Governance: The Rise and Evolution of Forest, Coffee, and Fisheries Certification (Yale University Press, 2014); Daniel Jaffee, Brewing Justice: Fair Trade Coffee, Sustainability and Survival (University of California Press, 2007); Gavin Fridell, Fair Trade Coffee: The Prospects and Pitfalls of Market-Driven Social Justice (University of Toronto Press, 2007).

56 Fair Trade Music <www.fairtrademusicpdx.org >.

57 Fair Trade Music (23 November 2014) Facebook <www.facebook.com/Fair.Trade.Music> and Fair Trade Music (23 November 2014) Twitter <@Fairtrademusic $>$.

58 Lital Helman, 'Fair Trade Copyright' (2013) 36(2) Journal of Law \& the Arts 157.

59 Songwriters Association of Canada, Announcing the 'Fair Trade Music' Initiative (4 June 2013) <www.songwriters.ca/news/337/130604fairtrademusic.aspx>; Songwriters Association of Canada, Fair Trade Music: Letting the Light Shine In (22 October 2013) <www.songwriters.ca/ news/344/131022fairtrademusic.aspx>. 
of misunderstanding have been usefully fleshed out in the academic literature by industry proponents. ${ }^{60}$ This should help those who are thinking critically about policy reform take the idea of fair trade music more seriously.

The main advantages of deploying the fair trade certification concept in the creative industries related to its independence from government and consistency with market-oriented approaches. Just after the turn of the 21st century, in the heyday of Napster and before Apple's iTunes music store, copyright policy debates were heavily influenced by proposals for alternative compensation schemes. Such schemes would essentially be expanded versions of private copying levies, with fees being paid by internet service providers, hardware manufacturers, or other intermediaries. ${ }^{61}$ Most (though not all) proposals were for statutory, non-exclusive remuneration rights granted in exchange for immunity from liability for peer-to-peer file sharing.

A key reason alternative compensation schemes have not been adopted is the almost insurmountable difficulty of building the consensus necessary for such dramatic law reform. One virtue of a fair trade certification scheme is that it requires no legislative reforms at all. Success depends not on governments' political will but on creators' and consumers' ability to insist on fair and equitable behaviour by industry intermediaries. While nobody would equate music creators with poor farmers in developing countries, this is not the point of the initiative. The point is to provide ethical consumers with a signal so that they can make informed choices in the marketplace. What those signals are, and whether the market embraces them, depend entirely on what consumers want, not any prescriptive policy direction on what consumers should want.

The idea of certified fair trade music (or other cultural works) harnesses rather than hinders the power of the market to promote public interests. Because it is entirely consistent with the general market-oriented framework that theoretically and doctrinally underpins copyright,

60 Eddie Schwartz, 'Coda: fair trade music: letting the light shine in' in Susy Frankel and Daniel Gervais (eds), The Evolution and Equilibrium of Copyright in the Digital Age (Cambridge University Press, 2014), 312.

61 For discussion and analysis of various proposals, see Jeremy de Beer, 'The Role of Levies in Canada's Digital Music Market' (2005) 4(3) Canadian Journal of Law \& Technology 153. 
it is likely to succeed. This demonstrates yet another way in which to mitigate what might otherwise be inequitable impacts of streamlining copyright structures to grow the size of creative industries overall.

\section{Conclusion}

This chapter has demonstrated that existing copyright policy is soundly premised on facilitating exchanges of proprietary rights in the free market. The layered and fragmented doctrinal structure of copyright, however, is often too complex to promote efficient market transactions. Well-established economic theory and practice indicates that simplifying and streamlining copyright in order to reduce royalty stacking would grow the size of the creative industries. This would lead to more innovation through market competition, more choice for consumers, more paths to market for creators, and more wealth generated through copyright assignments and licensing.

Free market mechanisms to grow the creative industries may, however, exacerbate inequalities through the uneven distribution of economic benefits among creators, intermediaries, and consumers. There is a risk that streamlining copyright markets will further concentrate wealth and power in the hands of creative industry intermediaries, including traditional publishers and producers as well as digital retailers and service providers.

Rather than relying entirely on doctrinal reforms internal to copyright to protect the public interest in ensuring the fair and equitable allocation of economic benefits, this chapter proposes several external marketplace framework mechanisms to complement copyright policy. Such mechanisms include collective bargaining, class proceedings, and certification schemes. The conclusion to be drawn from a discussion of these ideas is not that any one is a panacea for the public interest. Rather, this chapter has shown that a market-oriented approach to copyright, in the context of broader market regulatory frameworks and liberal economic policymaking generally, can work for creators, consumers, and the public interest. 
This text is taken from What if we could reimagine copyright?, edited by Rebecca Giblin and Kimberlee Weatherall, published 2017 by ANU Press, The Australian National University, Canberra, Australia. 